\title{
Penerapan Metode Clustering dengan Fuzzy C-Means untuk Memetakan Daerah Rawan Kecelakaan Lalu Lintas di Surakarta
}

\author{
Ignatius Bagas Ristanto ${ }^{1)}$, Yustina Retno Wahyu Utami ${ }^{2)}$, Teguh Susyanto ${ }^{3)}$ \\ ${ }^{1,2)}$ Program Studi Informatika, STMIK Sinar Nusantara Surakarta \\ 3) Program Studi Sistem Informasi, STMIK Sinar Nusantara Surakarta \\ 1) ignabagas@gmail.com, ${ }^{2}$ yustina_retno@sinus.ac.id, ${ }^{3)}$ teguh@sinus.ac.id
}

\begin{abstract}
Along with the development of Surakarta's infrastructure, the need for transportation has also increased. Indirectly, it will also cause several problems that must be considered, such as traffic accidents. Data regarding traffic accidents can be used to classify road sections based on the characteristic similarity factor which is inherent in the data. The sample data in this research was 1429 accidents from 89 roads in Surakarta. The purpose of this research was to build a system to map traffic areas that are prone to the accidents. The clustering method used to get the expected results is the Fuzzy C-Means method. The results of accident data collection were displayed using tables and maps that describe the mapping of road sections in the jurisdiction of Surakarta regional police station. The variables used to cluster data are the number of accidents, the number of died victims, and the number of injured victims. The result of this research is a system application that can classify accident-prone areas using the Fuzzy C-Means method into 3 clusters. Those are 5 data for its first cluster, 20 data for its second cluster, and 64 data for its third cluster.
\end{abstract}

Keywords: Mapping, Traffic Accident, Fuzzy C-Means, Clustering Data, Silhouette Index

\section{PENDAHULUAN}

Seiring perkembangan Kota Surakarta, maka jumlah penduduk di Kota Surakarta juga mengalami peningkatan. Menurut data dari badan pusat statistik kota Surakarta, jumlah penduduk kota Surakarta tahun 2017 sebnyak 516.102 jiwa, tahun 2017 sebanyak 517.887 jiwa dan tahun 2019 sebanyak 519.587. Dari data tiga tahun tersebut peningkatan jumlah penduduk lebih dari 1.500 jiwa. Dari peningkatan jumlah penduduk tersebut juga akan mempengaruhi kebutuhan transportasi yang akan terus meningkat. Badan pusat statistik kota Surakarta mencatat ada 26.891 kendaraan bermotor yang telah diregistrasi di tahun 2019, data ini mengalami peningkatan dari tahun sebelumnya.

Menurut data Kepolisian Resort Kota Surakarta menunjukkan adanya fluktuasi peristiwa kecelakaan lalu lintas di Surakarta. Angka kecelakaan di tahun 2017 pada bulan Januari hingga Desember, ada sebanyak 672 kejadian. Sedangkan angka kecelakaan di tahun 2018 sebanyak 834 kejadian dan di tahun 2019 sebanyak 1086 kejadian. Untuk mengatasi masalah tingkat kecelakaan lalu lintas yang tinggi, dibutuhkan upaya pencegahaan maupun penanganan.

Dari pemaparan data tersebut maka perlu adanya pemetaan daerah rawan kecelakaan lalu lintas menggunakan metode Fuzzy C-Means. Hasil dari pemetaan daerah rawan kecelakaan menjadi informasi kepada masyarakat khususnya pengguna jalan, dan pihakpihak yang terkait misalnya Dinas Satlantas untuk penanganan kecelakaan dan Dinas Pekerjaan Umum dan Penataan Ruang terkait dengan perbaikan jalan dan penunjangnya yang menjadi salah satu faktor penyebab terjadinya kecelakaan. Metode Fuzzy C-means dipilih untuk memetakan daerah rawan kecelakaan dikarenakan sudah ada penelitian tentang pemetaan daerah rawan kecelakaan menggunakan metode Fuzzy C-Means (Puspitasari et al., 2019). Teknik pengklasteran secara klasik dimana suatu obyek hanya akan menjadi anggota suatu klaster tertentu, dalam Fuzzy C-Means setiap data bisa menjadi anggota dari beberapa cluster, berdasarkan karakteristik inilah Fuzzy C Means 
dinilai sesuai untuk memetakan daerah rawan kecelakaan karena satu titik lokasi daerah rawan kecelakaan ini bisa memiliki lebih dari satu klaster.

Aplikasi pemetaan daerah rawan kecelakaan lalu lintas di kota Surakarta bertujuan untuk membantu memberikan informasi kepada dinas terkait maupun ke masyarakat khususnya pengguna jalan tentang daerah ruas jalan rawan kecelakaan.

\section{TINJAUAN PUSTAKA}

\subsection{Penelitian Sebelumnya}

Mengacu para beberapa penelitian sebelumnya yang yang sebagian besar mengkaji permasalahan pemetaan daerah rawan kecelakaan (Pradipta et al., 2018), (Feryanti \& Mulyono, 2019), (Arumsari et al., 2016), (Rozzaqiyah et al., 2017).

Penelitian (Pradipta et al., 2018) melakukan pemetaan daerah rawan kecelakaan di kecamatan banyumanik dan tembalang kabupaten Semarang berdasarkan jumlah kecelakaan dan kondisi korban kecelakaan. Pembagian klaster terdiri dari tiga kriteria yaitu rawan, cukup rawan dan aman. Metode yang digunakan untuk melakukan pemetaannya yaitu Cluster Analysis. Metode Cluster Analysis juga diterapkan oleh (Arumsari et al., 2016) untuk memetakan daerah rawan kecelakaan di Kabupaten Boyolali berdasarkan faktor jumlah kajadian, titik lokasi dan waktu kejadian. Sementara itu (Feryanti \& Mulyono, 2019) mengusulkan pemetaan karakteristik kecelakaan yang terjadi di kota Surakarta berdasarkan tingkat kecelakaan, tingkat penderitaan korban, faktor penyebab kecelakaan, waktu kecelakaan, tipe tabrakan, jenis kelamin pelaku maupun korban. Metode yang diterapkan dalam penelitian ini adalah kombinasi dari metode Angka Ekivalen Kecelakaan (AEK), Transport Research Laboratory (TRL). Hasil yang diperoleh berupa tabel data klasterisasi kecelakaan. Paper (Rozzaqiyah et al., 2017) mengusulkan sebuah aplikasi untuk pemetaan lokasi kecelakaan di daerah Bengkulu dengan menerapkan teknologi Location Based Service (LBS).

Paper ini mengusulkan pembuatan sistem aplikasi pemetaan daerah rawan kecelakaan di wilayah Kota Surakarta dengan menerapkan algoritma Fuzzy C-Means. Klasterisasi data kecelakaan ditentukan berdasarkan dari jumlah kejadian, jumlah korban luka-luka dan meninggal dan titik lokasi kejadian.

\subsection{Clustering}

Clustering atau klasterisasi adalah metode pengelompokan data. Clustering adalah sebuah proses untuk mengelompokan data ke dalam beberapa cluster atau kelompok, sehingga data dalam satu cluster memiliki tingkat kemiripan yang maksimum dan data antar cluster memiliki kemiripan yang minimum(Prasetyo, 2014). Clustering merupakan proses partisi satu set objek data ke dalam himpunan bagian yang disebut dengan cluster. Pengklasteran merupakan satu dari sekian banyak fungsi proses data mining untuk menemukan kelompok atau identifikasi kelompok obyek yang hampir sama.

\subsection{Kecelakaan Lalu Lintas}

Kecelakaan lalu lintas adalah suatu peristiwa di jalan raya tidak diduga dan tidak disengaja melibatkan kendaraan dengan atau tanpa pengguna jalan lain yang mengakibatkan korban manusia dan atau kerugian harta benda (Undang-Undang No.22 Tahun 2009, Tentang Lalu Lintas Dan Angkutan Jalan, 2009). Terdapat lima jenis dan bentuk kecelakaan lalu lintas, yaitu: berdasarkan korban kecelakaan, berdasarkan lokasi kejadian, berdasarkan waktu terjadinya, berdasarkan posisi kecelakaan, dan berdasarkan jumlah kendaraan yang terlibat. Di dalam terjadinya suatu kejadian kecelakaan selalu mengandung unsur ketidaksengajaan dan tidak disangka-sangka serta akan menimbulkan 
perasaan terkejut, heran dan trauma bagi orang yang mengalami kecelakaan tersebut (Maesaroh et al., 2017).

\subsection{Sistem Informasi Geografis}

Sistem Informasi Geografis (Geographic Information System / GIS) adalah sistem informasi khusus yang mengelola data yang memiliki informasi spasial (bereferensi keruangan). Secara umum pengertian Sistem Informasi Geografis adalah Suatu komponen yang terdiri dari perangkat keras, perangkat lunak, data geografis dan sumberdaya manusia yang bekerja bersama secara efektif untuk memasukan, menyimpan, memperbaiki, memperbaharui, mengelola, memanipulasi, mengintegrasikan, menganalisa dan menampilkan data dalam suatu informasi berbasis geografis (Prahasta, 2009).

\section{METODE PENELITIAN}

\subsection{Pengumpulan Data}

Dilakukan observasi pengamatan langsung pada kantor Satlantas Polresta Surakarta dalam menangani pemetaaan daerah rawan kecelakaan lalulintas di Kota Surakarta. Data yang diamati adalah sistem dokumentasi data kecelakaan pada komputer dan peta hasil pemetaan daerah rawan kecelakaan. Kemudian dilakukan wawancara tanya jawab secara langsung kepada kasatlantas dan petugas unit laka lantas mengenai cara penentuan daerah rawan kecelakaan lalulintas di Surakarta, serta data yang tersedia di Satlantas Polresta Surakarta. Studi pustaka ialah segala usaha yang dilakukan oleh peneliti untuk menghimpun informasi data yang relevan dengan topik atau masalah yang akan atau sedang diteliti. Informasi tersebut diperoleh dari buku-buku ilmiah, karya ilmiah, laporan penelitian, peraturan perundang-undangan yang terkait dengan kecelakaan lalu lintas. Pengumpulan data kecelakaan lalu lintas diperoleh dalam bentuk file data laporan dari dinas Satlantas. Dalam penelitian ini penulis memperoleh data laporan kecelakaan periode 2018-2019.

\subsection{Klasterisasi Data Kecelakaan}

Data yang dijadikan sebagai data kriteria yaitu data jumlah kejadian kecelakaan, data jumlah korban meninggal dan data jumlah korban luka-luka. Sedangkan data alternatif adalah data kecelakaan yang terjadi di 89 ruas jalan yang tersebar di 5 kecamatan di Surakarta. Kemudian menyiapkan data laporan kecelakaan yang diolah dengan mengklasifikasikannya terlebih dahulu berdasarkan ruas jalan. Data kemudian diolah dan dibagi menjadi 3 cluster yaitu daerah sangat rawan, rawan dan tidak rawan.

Fuzzy C-Means (FCM) adalah suatu teknik pengklasteran data yang keberadaan tiaptiap data dalam suatu cluster ditentukan oleh nilai/derajat keanggotaan tertentu.(Prasetyo, 2014) Teknik ini pertama kali diperkenalkan oleh Jim Bezdek pada tahun 1981. Konsep dasar FCM, pertama kali adalah menentukan pusat cluster yang akan menandai lokasi ratarata untuk tiap- tiap cluster. Pada kondisi awal, pusat cluster ini masih belum akurat. Tiaptiap data memiliki derajat keanggotaan untuk tiap-tiap cluster. Dengan cara memperbaiki pusat cluster dan nilai keanggotaan tiap-tiap data secara berulang, maka akan terlihat bahwa pusat cluster akan bergerak menuju lokasi yang tepat. Perulangan ini didasarkan pada minimasi fungsi obyektif. Output dari FCM merupakan deretan pusat cluster dan beberapa derajat keanggotaan untuk tiap-tiap titik data.

Maka, algoritma Fuzzy C-Means ( FCM ) diberikan sebagai berikut (Prasetyo, 2014): 1. Menentukan data yang akan di cluster $\mathrm{X}$, berupa matriks berukuran $\mathrm{n} \times \mathrm{m}(\mathrm{n}=$ jumlah sampel data, $\mathrm{m}=$ atribut setiap data). Xij = data sampel ke-i $(\mathrm{i}=1,2, \ldots, \mathrm{n})$, atribut ke-j $(j=1,2, \ldots, m)$. 
2. Menentukan:

- Jumlah cluster $\quad=\mathrm{c}$

- Pangkat $=w$

- Maksimum iterasi = MaxIter

- Error terkecil $=\xi$

- Fungsi objektif awal $=P_{O}=0$

- Interasi awal $\quad=t=1$

3. Membangkitkan bilangan random $\mu \mathrm{ik}, \mathrm{i}=1,2,3$..., $\mathrm{n} ; \mathrm{k}=1,2,3$...c; sebagai elemenelemen matriks partisi awal.

Menghitung jumlah setiap kolom:

$$
\mathrm{Q}_{\mathrm{i}=\Sigma_{k=1}^{c}}^{c} \mu_{i k}
$$

dengan $\mathrm{j}=1,2, \ldots \mathrm{n}$

menghitung:

$$
\mu_{i k}=\frac{\mu_{i k}}{Q_{i}}
$$

4. Menghitung pusat cluster ke-k: $\mathrm{V}_{\mathrm{kj}}$, dengan $\mathrm{k}=1,2, \ldots \mathrm{c}$; dan $\mathrm{j}=1,2, \ldots \mathrm{m}$

$$
V_{k j}=\frac{\Sigma_{i}^{n}\left(\left(\mu_{i k}\right)^{w}+X_{i j}\right)}{\Sigma_{i}^{n}\left(\mu_{i k}\right)^{w}}
$$

5. Menghitung fungsi objektif pada interasi ke-t:

$$
P t=\Sigma_{i=1}^{n} \Sigma_{k=1}^{c}\left[\Sigma_{j=1}^{m}\left(X_{i j}-V_{k j}\right)^{2}\left(\mu_{i k}\right)^{w}\right.
$$

6. Menghitung perubahan matriks partisi :

$$
\mu_{i k}=\frac{\left[\Sigma_{j=1}^{m}\left(X_{i j}-V_{k j}\right)^{2}\right]^{\frac{-1}{w-1}}}{\Sigma_{k=1}^{c}\left[\Sigma_{j=1}^{m}\left(X_{i j}-V_{k j}\right)^{2}\right]^{\frac{-1}{w-1}}}
$$

dengan: $\mathrm{i}=1,2, \ldots \mathrm{n}$; dan $\mathrm{k}=1,2, \ldots \mathrm{c}$.

7. Memeriksa kondisi berhenti:

- Jika: $(|\mathrm{Pt}-\mathrm{Pt}-1|<\xi)$ atau ( $\mathrm{t}>$ MaxIter) maka berhenti.

- Jika tidak: $\mathrm{t}=\mathrm{t}+1$, mengulang langkah ke-4.

\subsection{Rancangan Aplikasi}

Pada penelitian ini dibangun sebuah aplikasi berbasis web dengan menggunakan bahasa pemrograman PHP dan database MySQL untuk mempermudah dalam implementasi dan analisis algoritma Fuzzy C-Means. Aplikasi in terdiri dari 2 user yaitu sebagai admin dan user biasa dengan hak akses yang berbeda. Terdapat 6 halaman untuk masuk sebagai admin dan hanya 1 halaman untuk user biasa.

\section{HASIL DAN PEMBAHASAN}

Sistem yang dikembangkan difokuskan pada pemetaan daerah rawan kecelakaan guna membantu dinas dan masyarakat khususnya pengguna jalan untuk lebih berhati-hati dalam bekendara dan dapat mengurangi angka kecelakaan.

Proses clustering dilakukan dengan menetapkan nilai awal sebagai berikut:

1. Jumlah cluster yang akan dibentuk $=3$ yaitu daerah yang sangat sangat rawan, daerah rawan dan daerah aman. 
2. Pangkat pembobot $=3$

3. Kriteria penghentian $=0,000001$

4. Fungsi objektif awal $=0$

5. Nilai iterasi awal $=1$

Langkah pertama perhitungan Fuzzy C-Means yaitu menentukan derajat keanggotaan melalui matrik partisi U yang dibentuk secara random. Kemudian menghitung nilai miu $(\mu)$ yang diperoleh dari derajat keanggotaan yang dipangkatkan dengan pembobot $(\mu)^{\mathrm{w}}$. Selanjutnya dikalikan dengan nilai X atau data kriteria yang ada. Menggunakan persamaan (3) dihitung pusat cluster (V) yang berasal dari total miu kuadrat dibagi total miu X1, X2 dan X3.

$$
V_{k j}=\frac{\Sigma_{i}^{n}\left(\left(\mu_{i k}\right)^{w} \times X_{i j}\right)}{\Sigma_{i}^{n}\left(\mu_{i k}\right)^{w}}=\frac{376,52}{20,93}=18,15576
$$

Berikut hasil pusat cluster yang diperoleh dalam Tabel 3:

Tabel 3. Pusat Cluster

\begin{tabular}{|c|r|r|r|r|}
\hline \multirow{2}{*}{ Cluster } & \multicolumn{4}{|c|}{ Pusat Cluster (V) } \\
\cline { 2 - 5 } & \multicolumn{1}{|c|}{$\mathrm{X} 1$} & \multicolumn{1}{|c|}{$\mathrm{X} 2$} & \multicolumn{1}{c|}{$\mathrm{X} 3$} & \multicolumn{1}{c|}{$\mathrm{X} 4$} \\
\hline V1 & 18,15576 & 1,143813 & 0,083134 & 20,1715241 \\
\hline V2 & 14,89241 & 1,058544 & 0,125 & 16,7958861 \\
\hline V3 & 13,20198 & 0,88953 & 0,04864 & 14,4880462 \\
\hline
\end{tabular}

Tabel 4. Pusat Cluster

\begin{tabular}{|c|c|c|c|c|c|c|c|}
\hline \multirow[t]{2}{*}{ No } & \multirow[t]{2}{*}{ Nama Ruas Jalan } & \multicolumn{3}{|c|}{$\begin{array}{c}\text { Derajat Keanggotaan (m) data } \\
\text { pada Cluster ke- }\end{array}$} & \multicolumn{3}{|c|}{ Cluster (C) ke- } \\
\hline & & 1 & 2 & 3 & 1 & 2 & 3 \\
\hline 1 & Jl. Adi Sucipto & $9,44 \mathrm{E}-01$ & $1,85 \mathrm{E}-02$ & $3,79 \mathrm{E}-02$ & $\mathrm{x}$ & & \\
\hline 2 & Jl. Adi Sucipto & $2,87 \mathrm{E}-03$ & $2,40 \mathrm{E}-02$ & $9,73 \mathrm{E}-01$ & & $\mathrm{x}$ & \\
\hline 3 & Jl. Adi Sumarmo & $2,92 \mathrm{E}-02$ & $8,23 \mathrm{E}-02$ & $8,88 \mathrm{E}-01$ & & $\mathrm{x}$ & \\
\hline 4 & Jl. Ahmad Yani & $2,97 \mathrm{E}-03$ & $3,06 \mathrm{E}-02$ & $9,66 \mathrm{E}-01$ & $\mathrm{x}$ & & \\
\hline 5 & Jl. Ahmad Yani & $1,16 \mathrm{E}-02$ & $3,96 \mathrm{E}-01$ & $5,92 \mathrm{E}-01$ & & $\mathrm{x}$ & \\
\hline 6 & Jl. Ahmad Yani & $9,84 \mathrm{E}-01$ & $5,76 \mathrm{E}-03$ & $1,01 \mathrm{E}-02$ & & $\mathrm{x}$ & \\
\hline 7 & Jl. Arifin & $4,07 \mathrm{E}-03$ & $9,55 \mathrm{E}-01$ & $4,14 \mathrm{E}-02$ & & & $\mathrm{x}$ \\
\hline 8 & Jl. Basuki Rahmat & $8,39 \mathrm{E}-04$ & $9,89 \mathrm{E}-01$ & $1,02 \mathrm{E}-02$ & & & $\mathrm{x}$ \\
\hline 9 & Jl. Bayangkara & $9,37 \mathrm{E}-03$ & $7,17 \mathrm{E}-01$ & $2,74 \mathrm{E}-01$ & & & $\mathrm{x}$ \\
\hline 10 & Jl. Bayangkara & $3,17 \mathrm{E}-04$ & $9,96 \mathrm{E}-01$ & $4,09 \mathrm{E}-03$ & & & $\mathrm{x}$ \\
\hline 11 & Jl. Brigjen Katamso & $1,77 \mathrm{E}-03$ & $1,13 \mathrm{E}-02$ & $9,87 \mathrm{E}-01$ & & $\mathrm{x}$ & \\
\hline 12 & Jl. Brigjen Sudiarto & $6,08 \mathrm{E}-04$ & $9,90 \mathrm{E}-01$ & $9,88 \mathrm{E}-03$ & & $\mathrm{x}$ & \\
\hline 13 & Jl. Brigjen Sudiarto & $1,16 \mathrm{E}-02$ & $4,87 \mathrm{E}-01$ & $5,01 \mathrm{E}-01$ & & & $\mathrm{x}$ \\
\hline 14 & Jl. DI Panjaitan & $1,36 \mathrm{E}-04$ & 9,98E-01 & $1,81 \mathrm{E}-03$ & & & $\mathrm{x}$ \\
\hline 15 & Jl. Diponegoro & $1,93 \mathrm{E}-03$ & 9,76E-01 & $2,18 \mathrm{E}-02$ & & & $\mathrm{x}$ \\
\hline 16 & $\begin{array}{l}\text { Jl. Dr. Cipto } \\
\text { Mangunkusumo }\end{array}$ & $1,13 \mathrm{E}-03$ & $9,86 \mathrm{E}-01$ & $1,33 \mathrm{E}-02$ & & & $\mathrm{x}$ \\
\hline 17 & Jl. Dr. Muwardi & $3,36 \mathrm{E}-06$ & $1,00 \mathrm{E}+00$ & $4,76 \mathrm{E}-05$ & & & $\mathrm{x}$ \\
\hline 18 & Jl. Dr. Muwardi & $2,92 \mathrm{E}-03$ & $9,66 \mathrm{E}-01$ & $3,12 \mathrm{E}-02$ & & & $\mathrm{x}$ \\
\hline 19 & Jl. Dr. Radjiman & $6,80 \mathrm{E}-01$ & $9,26 \mathrm{E}-02$ & $2,27 \mathrm{E}-01$ & & & $\mathrm{x}$ \\
\hline 20 & Jl. Dr. Radjiman & $1,53 \mathrm{E}-03$ & $9,81 \mathrm{E}-01$ & $1,76 \mathrm{E}-02$ & $\mathrm{x}$ & & \\
\hline 21 & \begin{tabular}{|l|} 
Jl. Dr. Radjiman \\
\end{tabular} & $5,17 \mathrm{E}-04$ & $9,92 \mathrm{E}-01$ & $7,12 \mathrm{E}-03$ & & & $\mathrm{x}$ \\
\hline 22 & Jl. Dr. Supomo & 1,13E-03 & $9,86 \mathrm{E}-01$ & $1,33 \mathrm{E}-02$ & & & $\mathrm{x}$ \\
\hline 23 & Jl. Dr. Wahidin & $1,40 \mathrm{E}-04$ & $9,98 \mathrm{E}-01$ & $2,11 \mathrm{E}-03$ & & & $\mathrm{x}$ \\
\hline 25 & Jl. Gajah Mada & $3,19 \mathrm{E}-03$ & $9,35 \mathrm{E}-01$ & $6,16 \mathrm{E}-02$ & & & $\mathrm{x}$ \\
\hline 26 & Jl. Gatot Subroto & $5,61 \mathrm{E}-04$ & $9,90 \mathrm{E}-01$ & $9,09 \mathrm{E}-03$ & & & $\mathrm{x}$ \\
\hline 27 & Jl. Gotong Royong & $2,92 \mathrm{E}-03$ & $9,66 \mathrm{E}-01$ & $3,12 \mathrm{E}-02$ & & & $\mathrm{x}$ \\
\hline 28 & Jl. Hasanudin & $5,18 \mathrm{E}-04$ & $9,93 \mathrm{E}-01$ & $6,50 \mathrm{E}-03$ & & & $\mathrm{x}$ \\
\hline 29 & Jl. Hasanudin & $8,20 \mathrm{E}-03$ & $7,71 \mathrm{E}-01$ & $2,21 \mathrm{E}-01$ & & & $\mathrm{x}$ \\
\hline 30 & Jl. Honggowongso & $2,43 \mathrm{E}-03$ & $9,71 \mathrm{E}-01$ & $2,66 \mathrm{E}-02$ & & & $\mathrm{x}$ \\
\hline 31 & Jl. Honggowongso & $4,85 \mathrm{E}-05$ & $9,99 \mathrm{E}-01$ & 6,88E-04 & & & $\mathrm{x}$ \\
\hline 32 & \begin{tabular}{|l} 
Jl. Hos Cokro \\
Aminoto
\end{tabular} & $1,40 \mathrm{E}-04$ & 9,98E-01 & $2,11 \mathrm{E}-03$ & & & $\mathrm{x}$ \\
\hline 33 & Jl. Ir. Juanda & $3,10 \mathrm{E}-01$ & $1,59 \mathrm{E}-01$ & $5,32 \mathrm{E}-01$ & & $\mathrm{x}$ & \\
\hline 34 & Jl. Ir. Sutami & $6,53 \mathrm{E}-01$ & $1,01 \mathrm{E}-01$ & $2,46 \mathrm{E}-01$ & $\mathrm{x}$ & & \\
\hline 35 & Jl. Jenderal & $1,55 \mathrm{E}-04$ & $9,98 \mathrm{E}-01$ & $2,21 \mathrm{E}-03$ & & & $\mathrm{x}$ \\
\hline
\end{tabular}

\begin{tabular}{|c|c|c|c|c|c|c|c|}
\hline \multirow[t]{2}{*}{ No } & \multirow[t]{2}{*}{ Nama Ruas Jalan } & \multicolumn{3}{|c|}{$\begin{array}{c}\text { Derajat Keanggotaan (m) data } \\
\text { pada Cluster ke- }\end{array}$} & \multicolumn{3}{|c|}{ Cluster (C) ke- } \\
\hline & & 1 & 2 & 3 & 1 & 2 & 3 \\
\hline & Soedirman & & & & & & \\
\hline 36 & Jl. Joko Tingkir & $2,45 \mathrm{E}-03$ & $9,71 \mathrm{E}-01$ & $2,68 \mathrm{E}-02$ & & & $\mathrm{x}$ \\
\hline 37 & Jl. Kapten Mulyadi & $9,07 \mathrm{E}-02$ & $1,35 \mathrm{E}-01$ & 7,75E-01 & & $\mathrm{x}$ & \\
\hline 38 & Jl. Kapten Mulyadi & $1,40 \mathrm{E}-04$ & $9,98 \mathrm{E}-01$ & $2,11 \mathrm{E}-03$ & & & $\mathrm{x}$ \\
\hline 39 & $\begin{array}{l}\text { Jl. Kapten Piere } \\
\text { Tendean }\end{array}$ & $1,19 \mathrm{E}-02$ & 3,77E-01 & $6,11 \mathrm{E}-01$ & & $\mathrm{x}$ & \\
\hline 40 & $\begin{array}{l}\text { Jl. Kebangkitan } \\
\text { Nasional }\end{array}$ & $8,51 \mathrm{E}-05$ & 9,99E-01 & $1,24 \mathrm{E}-03$ & & & $\mathrm{x}$ \\
\hline 41 & Jl. Kerinci & $1,13 \mathrm{E}-03$ & 9,86E-01 & $1,33 \mathrm{E}-02$ & & & $\mathrm{x}$ \\
\hline 24 & Jl. KH. Agus Salim & $2,94 \mathrm{E}-04$ & $9,96 \mathrm{E}-01$ & $3,90 \mathrm{E}-03$ & & & $\mathrm{x}$ \\
\hline 42 & Jl. KH. Samanhudi & $4,52 \mathrm{E}-03$ & $9,00 \mathrm{E}-01$ & $9,51 \mathrm{E}-02$ & & & $\mathrm{x}$ \\
\hline 43 & \begin{tabular}{|l|} 
Jl. Ki Hajar \\
Dewantara
\end{tabular} & $8,07 \mathrm{E}-03$ & $1,44 \mathrm{E}-01$ & $8,48 \mathrm{E}-01$ & & $\mathrm{x}$ & \\
\hline 44 & $\begin{array}{l}\text { Jl. Ki Mangun } \\
\text { Sarkoro }\end{array}$ & $1,27 \mathrm{E}-03$ & $1,15 \mathrm{E}-02$ & $9,87 \mathrm{E}-01$ & & $\mathrm{x}$ & \\
\hline 45 & Jl. Kolonel Sugiono & $4,72 \mathrm{E}-03$ & $2,36 \mathrm{E}-02$ & 9,72E-01 & & $\mathrm{x}$ & \\
\hline 46 & JI. Kolonel Sutarto & $5,94 \mathrm{E}-03$ & $2,87 \mathrm{E}-02$ & $9,65 \mathrm{E}-01$ & & $\bar{x}$ & \\
\hline 47 & Jl. Kyai Mojo & $8,82 \mathrm{E}-03$ & $7,35 \mathrm{E}-01$ & $2,57 \mathrm{E}-01$ & & & $\mathrm{x}$ \\
\hline 48 & Jl. Letjend Suprapto & $8,51 \mathrm{E}-05$ & $9,99 \mathrm{E}-01$ & $1,24 \mathrm{E}-03$ & & & $\mathrm{x}$ \\
\hline 49 & Jl. Letjend Sutoyo & $8,85 \mathrm{E}-03$ & 7,37E-01 & $2,54 \mathrm{E}-01$ & & & $\mathrm{x}$ \\
\hline 50 & Jl. Letjend Sutoyo & $1,36 \mathrm{E}-04$ & $9,98 \mathrm{E}-01$ & $1,81 \mathrm{E}-03$ & & & $\mathrm{x}$ \\
\hline 51 & Jl. Mayor Achmadi & $1,40 \mathrm{E}-04$ & 9,98E-01 & $2,11 \mathrm{E}-03$ & & & $\mathrm{x}$ \\
\hline 52 & Jl. Mayor Sunaryo & $1,13 \mathrm{E}-03$ & $9,86 \mathrm{E}-01$ & $1,33 \mathrm{E}-02$ & & & $\mathrm{x}$ \\
\hline 53 & Jl. Mayor Sunaryo & $1,93 \mathrm{E}-03$ & $9,76 \mathrm{E}-01$ & $2,18 \mathrm{E}-02$ & & & $\mathrm{x}$ \\
\hline 54 & Jl. Menteri Supeno & $4,07 \mathrm{E}-03$ & $9,55 \mathrm{E}-01$ & $4,14 \mathrm{E}-02$ & & & $\mathrm{x}$ \\
\hline 55 & Jl. Mojo & $1,93 \mathrm{E}-03$ & $9,76 \mathrm{E}-01$ & $2,18 \mathrm{E}-02$ & & & $\mathrm{x}$ \\
\hline 56 & Jl. Mongisidi & $3,60 \mathrm{E}-04$ & $9,95 \mathrm{E}-01$ & $4,67 \mathrm{E}-03$ & & & $\mathrm{x}$ \\
\hline 57 & Jl. Mongisidi & 6,60E-03 & $8,29 \mathrm{E}-01$ & $1,64 \mathrm{E}-01$ & & & $\mathrm{x}$ \\
\hline 58 & Jl. MT. Haryono & $5,65 \mathrm{E}-05$ & 9,99E-01 & $8,29 \mathrm{E}-04$ & & & $\mathrm{x}$ \\
\hline 59 & \begin{tabular}{|l} 
Jl. Prof Dr. \\
Soeharso
\end{tabular} & 3,43E-04 & 9,95E-01 & $4,42 \mathrm{E}-03$ & & & $\mathrm{x}$ \\
\hline 60 & JI. RE. Martadinata & 6,51E-03 & \begin{tabular}{|l|}
$8,33 \mathrm{E}-01$ \\
\end{tabular} & 1,61E-01 & & & $\mathrm{x}$ \\
\hline 61 & Jl. Ring Road & $9,68 \mathrm{E}-03$ & $8,30 \mathrm{E}-02$ & $9,07 \mathrm{E}-01$ & & $\mathrm{x}$ & \\
\hline 62 & Jl. RM Said & $8,54 \mathrm{E}-03$ & $1,65 \mathrm{E}-01$ & $8,27 \mathrm{E}-01$ & & $\mathrm{x}$ & \\
\hline 63 & Jl. Ronggowarsito & $5,74 \mathrm{E}-03$ & $8,59 \mathrm{E}-01$ & $1,36 \mathrm{E}-01$ & & & $\mathrm{x}$ \\
\hline 64 & Jl. S. Parman & $3,51 \mathrm{E}-03$ & $9,24 \mathrm{E}-01$ & $7,20 \mathrm{E}-02$ & & & $\mathrm{x}$ \\
\hline 65 & Jl. Samratulangi & $2,45 \mathrm{E}-03$ & $9,71 \mathrm{E}-01$ & $2,68 \mathrm{E}-02$ & & & $\mathrm{x}$ \\
\hline
\end{tabular}




\begin{tabular}{|c|l|c|c|c|c|c|c|}
\hline \multirow{2}{*}{ No } & \multirow{2}{*}{ Nama Ruas Jalan } & \multicolumn{3}{|c|}{$\begin{array}{c}\text { Derajat Keanggotaan (m) data } \\
\text { pada Cluster ke- }\end{array}$} & \multicolumn{2}{|c|}{ Cluster (C) ke- } \\
\hline & & 1 & 2 & 3 & 1 & 2 & 3 \\
\hline 66 & Jl. Samratulangi & $1,13 \mathrm{E}-03$ & $9,86 \mathrm{E}-01$ & $1,33 \mathrm{E}-02$ & & & x \\
\hline 67 & Jl. Setia Budi & $3,51 \mathrm{E}-03$ & $9,24 \mathrm{E}-01$ & $7,20 \mathrm{E}-02$ & & & x \\
\hline 68 & Jl. Slamet Riyadi & $7,55 \mathrm{E}-01$ & $1,00 \mathrm{E}-01$ & $1,45 \mathrm{E}-01$ & x & & \\
\hline 69 & Jl. Slamet Riyadi & $4,28 \mathrm{E}-03$ & $9,03 \mathrm{E}-01$ & $9,24 \mathrm{E}-02$ & & & x \\
\hline 70 & Jl. Slamet Riyadi & $2,05 \mathrm{E}-03$ & $9,60 \mathrm{E}-01$ & $3,75 \mathrm{E}-02$ & & & x \\
\hline 71 & Jl. Slamet Riyadi & $2,00 \mathrm{E}-03$ & $9,61 \mathrm{E}-01$ & $3,65 \mathrm{E}-02$ & & & x \\
\hline 72 & Jl. Sugiyopranoto & $4,07 \mathrm{E}-03$ & $9,55 \mathrm{E}-01$ & $4,14 \mathrm{E}-02$ & & & x \\
\hline 73 & Jl. Sumpah Pemuda & $3,51 \mathrm{E}-03$ & $9,24 \mathrm{E}-01$ & $7,20 \mathrm{E}-02$ & & & x \\
\hline 74 & Jl. Sumpah Pemuda & $1,93 \mathrm{E}-03$ & $1,86 \mathrm{E}-02$ & $9,79 \mathrm{E}-01$ & & x & \\
\hline 75 & Jl. Surya & $8,07 \mathrm{E}-03$ & $7,71 \mathrm{E}-01$ & $2,21 \mathrm{E}-01$ & & & x \\
\hline 76 & Jl. Sutan SyahrIr & $1,13 \mathrm{E}-03$ & $9,86 \mathrm{E}-01$ & $1,33 \mathrm{E}-02$ & & & x \\
\hline 77 & Jl. Sutan SyahrIr & $8,14 \mathrm{E}-04$ & $9,89 \mathrm{E}-01$ & $9,94 \mathrm{E}-03$ & & & x \\
\hline 78 & Jl. Tentara Pelajar & $9,53 \mathrm{E}-03$ & $6,97 \mathrm{E}-01$ & $2,94 \mathrm{E}-01$ & & & x \\
\hline
\end{tabular}

\begin{tabular}{|c|c|c|c|c|c|c|c|}
\hline \multirow[t]{2}{*}{ No } & \multirow[t]{2}{*}{ Nama Ruas Jalan } & \multicolumn{3}{|c|}{$\begin{array}{c}\text { Derajat Keanggotaan (m) data } \\
\text { pada Cluster ke- }\end{array}$} & \multicolumn{3}{|c|}{ Cluster (C) ke- } \\
\hline & & 1 & 2 & 3 & 1 & 2 & 3 \\
\hline 79 & Jl. Tentara Pelajar & $1,36 \mathrm{E}-04$ & $9,98 \mathrm{E}-01$ & $1,81 \mathrm{E}-03$ & & & $\mathrm{x}$ \\
\hline 80 & $\begin{array}{l}\text { Jl. Tuanku Imam } \\
\text { Bonjol }\end{array}$ & 2,92E-03 & $9,66 \mathrm{E}-01$ & $3,12 \mathrm{E}-02$ & & & $\mathrm{x}$ \\
\hline 81 & Jl. Untung Suropati & $3,36 \mathrm{E}-06$ & $1,00 \mathrm{E}+00$ & $4,76 \mathrm{E}-05$ & & & $\mathrm{x}$ \\
\hline 82 & Jl. Untung Suropati & $4,07 \mathrm{E}-03$ & $9,55 \mathrm{E}-01$ & $4,14 \mathrm{E}-02$ & & & $\mathrm{x}$ \\
\hline 83 & Jl. Urip Sumoharjo & $4,07 \mathrm{E}-03$ & $9,55 \mathrm{E}-01$ & $4,14 \mathrm{E}-02$ & & $\mathrm{x}$ & \\
\hline 84 & Jl. Urip Sumoharjo & $9,47 \mathrm{E}-03$ & $2,12 \mathrm{E}-01$ & $7,79 \mathrm{E}-01$ & & & $\mathrm{x}$ \\
\hline 85 & Jl. Veteran & $1,16 \mathrm{E}-02$ & $4,02 \mathrm{E}-01$ & $5,86 \mathrm{E}-01$ & & $\mathrm{x}$ & \\
\hline 86 & Jl. Veteran & $1,20 \mathrm{E}-02$ & $4,68 \mathrm{E}-02$ & $9,41 \mathrm{E}-01$ & & $\mathrm{x}$ & \\
\hline 87 & Jl. Yos Sudarso & $1,10 \mathrm{E}-04$ & $9,98 \mathrm{E}-01$ & $1,56 \mathrm{E}-03$ & & $\mathrm{x}$ & \\
\hline 88 & Jl. Yos Sudarso & $8,97 \mathrm{E}-04$ & $8,52 \mathrm{E}-03$ & $9,91 \mathrm{E}-01$ & & & $\mathrm{x}$ \\
\hline 89 & Jl. Yosodipuro & $2,88 \mathrm{E}-03$ & $9,40 \mathrm{E}-01$ & $5,68 \mathrm{E}-02$ & & & $\mathrm{x}$ \\
\hline \multicolumn{5}{|c|}{ Total } & 5 & 20 & 64 \\
\hline
\end{tabular}

Selanjutnya mencari nilai L kemudian ditotal $(\Sigma \mathrm{L})$ keseluruhan untuk menemukan fungsi objektif $(\mathrm{Pt})$. Pada iterasi pertama ini $\mathrm{Pt}=36988,65123$. Menghitung LT dengan rumus persamaan (4). Selanjutnya dihitung $\Sigma \mathrm{LT}$.

Kemudian hitung selisih fungsi objektif dengan mengurangi nilai fungsi objektif dengan iterasi sebelumnya. Khusus untuk iterasi pertama dikurangi nol (0). Jika selisih (Pt) fungsi objektif kurang dari error terkecil yang diharapkan maka iterasi berhenti. Jika tidak, maka selanjutnya menghitung perubahan matriks derajat kenggotaan baru dengan persamaan (5). Pada kasus ini iterasi berhenti pada iterasi ke-37 adapun hasil perhitungan dapat dilihat pada Tabel 4 .

Hasil yang diperoleh dari perhitungan 89 ruas jalan di Surakarta yaitu cluster 1 terdiri dari 5 ruas jalan, cluster 2 terdiri dari 20 ruas jalan, dan cluster 3 terdiri dari 64 ruas jalan. Data hasil perhitungan tersebut akan diolah menjadi sebuah peta daerah rawan kecelakaan.

\subsection{Implementasi}

Implementasi dari sistem pemetaan lalu lintas daerah rawan kecelakaan dapat dilihat sebagai berikut:

a. Tampilan Beranda

Pada tampilan beranda akan muncul pemetaan daerah rawan kecelakaan di Surakarta yang tampil berdasarkan kelompok cluster yang dibedakan berdasarkan warna. Keterangan warna serta informasi detail jalan ditampilkan menu slide pada peta. Tampilan beranda dapat dilihat pada Gambar 1 .

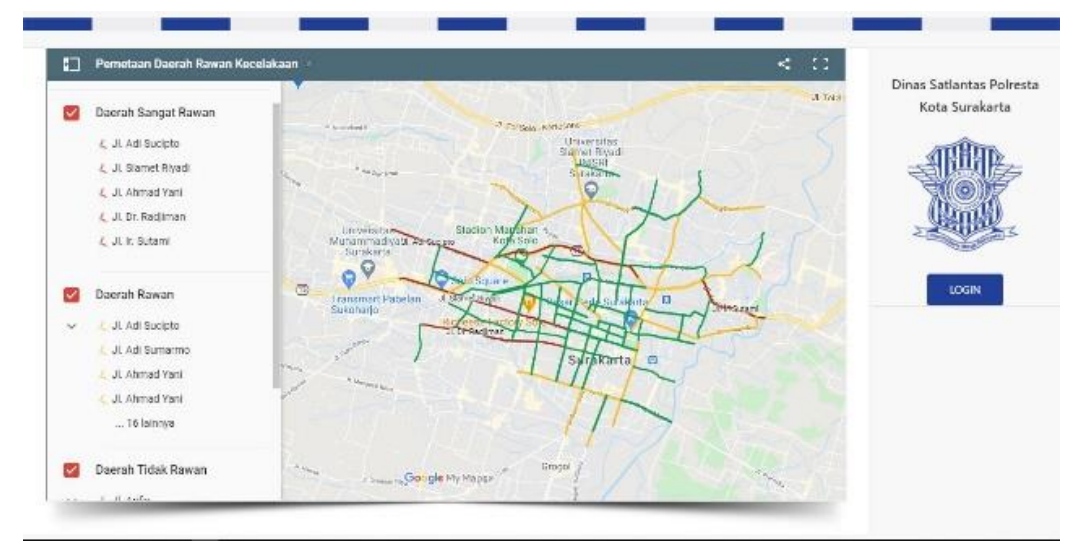

Gambar 1. Tampilan Beranda Awal

b. Proses Clustering

Halaman menu klasifikasi jalan rawan adalah halaman dimana admin mendapatkan informasi data jalan beserta jumlah kejadian, korban meninggal dan korban luka dalam 
bentuk tabel. Admin dapat memasukkan nilai untuk melakukan perhitungan clustering dengan metode Fuzzy C-Means. Tampilan halaman klasifikasi jalan rawan adalah seperti Gambar 2.

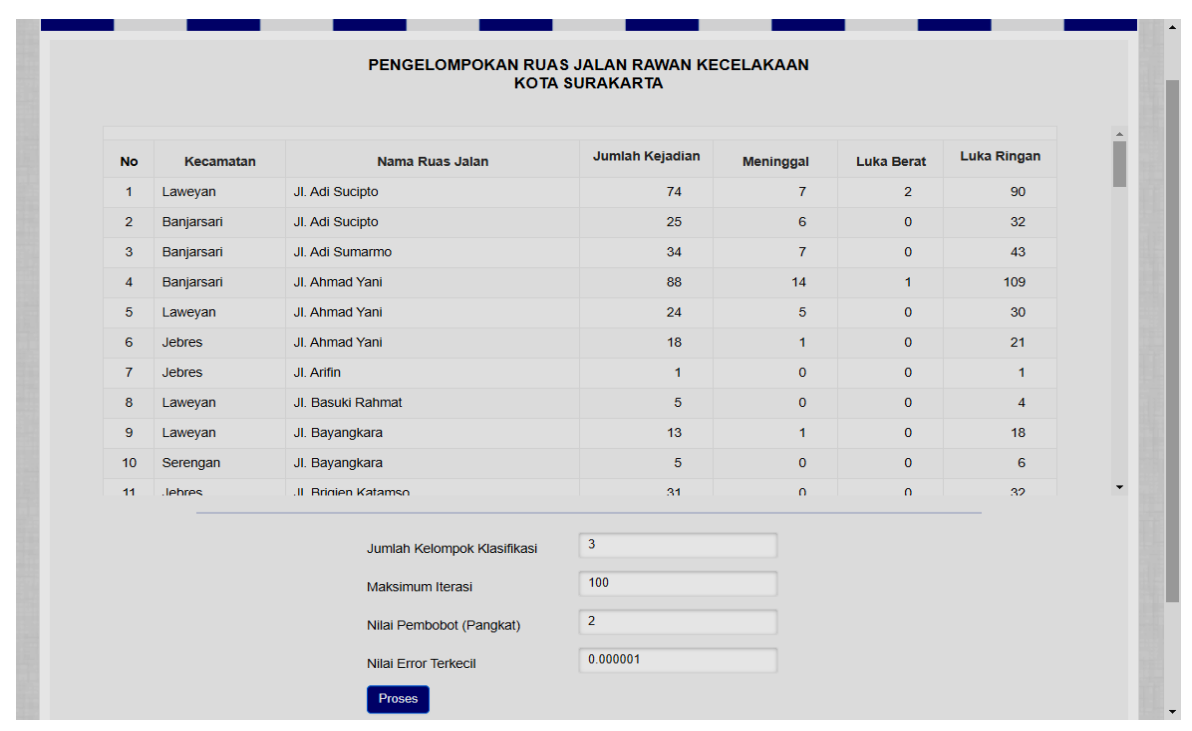

c. Laporan

Gambar 2. Tampilan Proses Clustering

Halaman menu analisis data kecelakaan adalah halaman dimana admin mendapatkan informasi hasil clustering data jalan beserta jumlah kejadian, korban meninggal dan korban luka dalam bentuk tabel. Tampilan halaman menu analisis data kecelakaan adalah seperti Gambar 3.

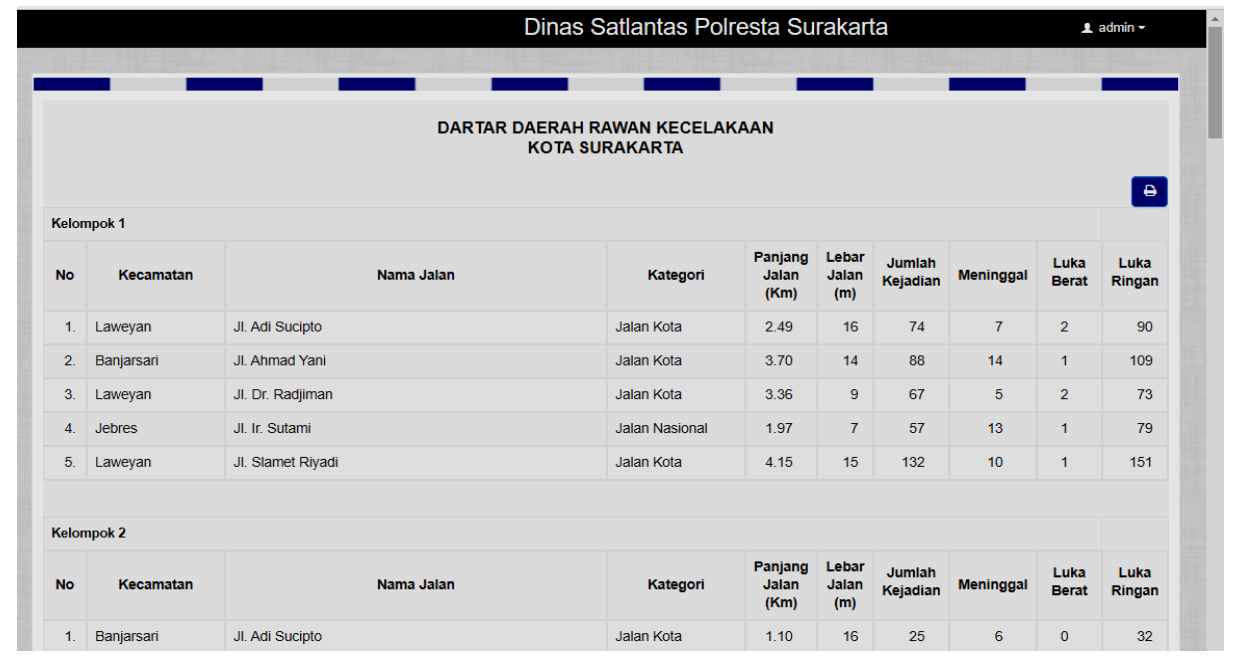

Gambar 3. Tampilan Proses Clustering

\subsection{Pengujian Sistem}

Silhouette Index (SI) digunakan untuk memvalidasi sebuah data dan keseluruhan cluster. Metode ini digunakan untuk memvalidasi cluster yang menggabungkan nilai kohesi dan separasi. Perhitungan nilai Silhouette Index terdapat dua komponen yakni a(i) dan b(i). a(i) adalah rata-rata jarak data ke-i dengan semua data lainnya dalam satu cluster, sedangkan $b(i)$ didapatkan dengan menghitung rata-rata jarak data ke-i terhadap semua data lainnya dalam satu cluster yang lain yang tidak dalam satu cluster dengan data ke-i, kemudian diambil yang terkecil. Hitung rata-rata jarak dari suatu data, terhadap semua data 
lain yang masih berada dalam satu $\operatorname{cluster}\left(a_{i}^{j}\right)$. Kemudian hitung rata-rata jarak data $i$ tersebut dengan semua data di cluster lain $\left(b_{i}^{j}\right)$, dan diambil nilai terkecilnya.

Untuk mendapatkan Silhouette Index (SI) data ke-i menggunakan persamaan berikut :

$$
S I_{i}^{j}=\frac{b_{i}^{j}-a_{i}^{j}}{\max \left\{a_{j}^{j}, b_{i}^{j}\right\}}
$$

Dimana:

$a$ : Rata-rata jarak data ke-i terhadap semua data lainnya dalam satu cluster $b$ : Nilai minimum dari rata-rata jarak data ke-i terhadap semua data dari cluster yang lain $\max \left(a_{i}^{j}, b_{i}^{j}\right)$ : Nilai maksimum dari nilai a dan $\mathrm{b}$ dari satu data

\section{SI: Silhouette Index}

Nilai SC didapat dengan mencari nilai maksimum SI global dari jumlah cluster sampai jumlah cluster $n-1$, seperti pada persamaan berikut :

$$
\begin{aligned}
& S I=\frac{1}{k} \sum_{j=1}^{k} S I_{j} \\
& S C=\operatorname{Max}_{j} S I(j)
\end{aligned}
$$

Dimana:

$\begin{array}{ll}\mathrm{k} & \text { : Jumlah Cluster } \\ \mathrm{j} & \text { : Cluster } \\ \mathrm{SC} & \text { : Silhouette Index Coefficient } \\ \mathrm{SI}_{\mathrm{j}} & \text { : Silhouette Index Cluster } \\ \mathrm{SI} & \text { : Silhouette Index } \text { global }\end{array}$

Kriteria subjektif pengukuran baik atau tidaknya pengelompokkan berdasarkan SC disajikan dalam tabel berikut (Kaufman \& Peter Rousseeuw, 1990):

Tabel 5. Nilai Silhouette Coefficient

\begin{tabular}{|c|c|}
\hline Nilai Silhouette Coefficient & Struktur \\
\hline $0.7<\mathrm{SC}<=1$ & Struktur Kuat \\
\hline $0.5<\mathrm{SC}<=0.7$ & Struktur Sedang \\
\hline $0.25<\mathrm{SC}<=0.5$ & Struktur Lemah \\
\hline $\mathrm{SC}<=0.25$ & Tidak Terstruktur \\
\hline
\end{tabular}

Menghitung rata-rata SI dalam setiap cluster dengan menggunakan rumus persamaan (7). Kemudian menghitung Nilai SC menggunakan persamaan (8). Berikut tabel nilai hasil perhitungan dari SI dalam setiap Cluster dan nilai akhir SC:

Tabel 6. Nilai Silhouette Coefficient

\begin{tabular}{|c|c|}
\hline \multicolumn{2}{|c|}{ SI Per Cluster } \\
\hline Cluster 1 & 0,42892 \\
\hline Cluster 2 & 0,38790 \\
\hline Cluster 3 & 0,68535 \\
\hline SC & $\mathbf{0 , 5 0 0 7 2}$ \\
\hline
\end{tabular}

Dalam tabel 6 tentang nilai Silhouette, dikatakan bahwa jika nilai Silhouette Coefisien jika nilai SC lebih dari 0,5 dan atau kurang dari sama dengan 0,7 maka clustering data berstruktur sedang.

Untuk pengujian hasil klaster, digunakan metode modified partition coefficient (MPC). MPC merupakan metode yang digunakan untuk menguji validitas jumlah klaster. Langkah pertama mencari PC(c) terlebih dahulu menggunakan persamaan berikut: 


$$
P C(c)=\frac{1}{n} \sum_{i=1}^{c} \sum_{j=1}^{n}\left(\mu_{i j} 2\right)=\frac{1}{89} 83,83575644=0,941974
$$

Kemudian melakukan perhitungan MPC(c) dengan menggunakan persamaan berikut:

$$
\begin{aligned}
\operatorname{MPC}(c) & =1-\frac{c}{c-1}(1-P C(c)) \\
& =1-\frac{2}{2-1}(1-0,941974)=0,883949
\end{aligned}
$$

Melakukan perhitungan hingga sampai 5 Cluster. Kemudian hasil MPC(c) terlihat seperti Tabel 6.

Tabel 6. Tabel MPC

\begin{tabular}{|c|c|}
\hline Jumlah Cluster & Nilai MPC(c) \\
\hline 2 & 0,88395 \\
\hline 3 & 0,80009 \\
\hline 4 & 0,81256 \\
\hline 5 & 0,765827 \\
\hline
\end{tabular}

Nilai MPC tertinggi ke terendah secara urut adalah pada 2 cluster, 4 cluster, 3 cluster dan terakhir 5 cluster.

Pengujian korelasi variabel independen terhadap hasil clustering digunakan untuk mengetahui kekuatan hubungan antara korelasi kedua variabel dimana variabel lainnya dianggap berpengaruh, dikendalikan atau dibuat tetap (sebagai variabel control). Variabel yang diteliti adalah data jumlah kejadian. Penentuan koefisien korelasi dengan menggunakan bantuan excel dengan rumus sebagai berikut: = CORREL (himpunan data kejadian; himpunan hasil cluster) $=0,393821577$.

Tabel 7. Tabel Koefisien Korelasi

\begin{tabular}{|c|c|}
\hline Interval Korelasi & Tingkat Hubungan \\
\hline $0,00-0,199$ & Sangat rendah \\
\hline $0,20-0,399$ & Rendah \\
\hline $0,40-0,599$ & Sedang \\
\hline $0,60-0,799$ & Kuat \\
\hline $0,80-1,000$ & Sangat Kuat \\
\hline
\end{tabular}

Dari hasil tersebut dapat disimpulkan ke dalam tabel Koefisien Korelasi (Sugiyono, 2014) bahwa tingkat hubungan variabel jumlah kejadian adalah rendah, meskipun rendah namun masih mempunyai pengaruh terhadap hasil clustering.

\section{KESIMPULAN DAN SARAN}

\subsection{Kesimpulan}

Pada pembuatan sistem pemetaan daerah rawan kecelakaan lalu lintas di Surakarta dengan metode Fuzzy C-Means (FCM) Clustering yang telah dibahas dapat disimpulkan sebagai berikut:

1. Perhitungan hasil cluster dipengaruhi oleh nilai variabel kriteria. Variabel baru jumlah kejadian yang ditambahkan mempunyai tingkat korelasi variabel yang rendah, artinya dengan metode Fuzzy C-Means variabel jumlah kejadian tidak berpengaruh secara signifikan.

2. Pengujian validasi cluster dengan metode Silhouette Index pada periode data kecelakaan tahun 2018-2019 menyatakan bahwa 3 cluster merupakan struktur yang sedang, dan data belum begitu tepat masuk ke dalam setiap Cluster.

3. Pengujian validasi cluster dengan metode MPC, jumlah cluster 3 merupakan jumlah cluster yang lebih baik jika dibandingkan dengan jumlah cluster 4 dan 5 . 
4. Pada penelitian pemetaan daerah rawan kecelakaan lalu lintas di Surakarta ini menghasilkan cluster $1=5$ ruas jalan, cluster $2=20$ ruas jalan, dan cluster $3=64$ ruas jalan.

5. Aplikasi yang dibuat mampu menampilkan data ruas jalan yang sudah di cluster berupa tabel dan mampu menampilkan ruas jalan rawan kecelakaan yang sudah di cluster. Sehingga dapat lebih mudah dalam melakukan sosialisasi terhadap ruas jalan yang dikategorikan daerah sangat rawan kecelakaan maupun daerah rawan kecelakaan.

\subsection{Saran}

Adapun saran yang ingin penulis sampaikan adalah sebagai berikut :

1. Perlu dilakukan proses penambahan variabel agar hasil clustering yang dihasilkan dapat lebih maksimal.

2. Sistem yang telah dibuat menggunakan perhitungan fuzzy c-means. Diharapkan dapat dikembangkan dengan mengkombinasi dengan beberapa metode lain, misalnya metode K-Means atau metode Angka Ekivalen Kecelakaan (AEK).

3. Aplikasi ini dapat dikembangkan lebih dalam lagi sehingga dapat berjalan di sistem operasi mobile dalam bentuk aplikasi mobile.

Penelitian selanjutnya diharapkan untuk menambah fungsi dari aplikasi pemetaan daerah rawan kecelekaan ini sehingga tidak hanya menampilkan ruas jalan rawan kecelakaan tetapi juga dapat sebagai navigator untuk pengguna jalan sehingga dapat menghindari jalan-jalan yang memang rawan kecelakaan.

\section{DAFTAR PUSTAKA}

Arumsari, N. D., Arief Laila Nugraha, \& Moehammad Awaluddin. (2016). Pemodelan Daerah Rawan Kecelakaan Dengan Menggunakan Cluster Analysis. Geodesi Undip, 5(Data Mining), 174-183.

Feryanti, I. K., \& Mulyono, G. S. (2019). Analisis Kecelakaan Lalu Lintas di Kota Surakarta. Universitas Muhammadiyah Surakarta.

Kaufman, L., \& Peter Rousseeuw. (1990). Finding Groups in Data: An Introduction to Cluster Analysis. John Wiley \& Sons, Inc.

Maesaroh, S., Sunaryo, D. K., \& Noraini, A. (2017). Analisis Daerah Rawan Kecelakaan Lalu Lintas Tahun 2017 Dengan Cluster Analysis (Studi Kasus: Kabupaten Pati). Institut Teknologi Nasional Malang.

Pradipta, A. D. R., Awaluddin, M., \& Nugraha, A. L. (2018). Pemetaan Daerah Rawan Kecelakaan Di Kota Semarang Dengan Menggunakan Metode Cluster Analysis (Studi Kasus : Kecamatan Banyumanik Dan Tembalang). Jurnal Geodesi Undip, 7(4), 185194.

Prahasta, E. (2009). Sistem Informasi Geografis Konsep - Konsep Dasar (Perpekstif Geodesi dan Geomatika). Informatika.

Prasetyo, E. (2014). Data Mining Mengolah Data Menjadi Informasi Menggunakan Matlab. Andi Offset.

Puspitasari, D., Syaifudin, Y. W., \& Nofyandi, R. D. (2019). Pemetaan Daerah Rawan Kecelakaan Menggunakan Metode Fuzzy C-Means. Jurnal Informatika Polinema, 5(2), 90-95. https://doi.org/10.33795/jip.v5i2.260

Rozzaqiyah, R., Erlansari, A., \& Anggriani, K. (2017). Web Gis Pemetaan Lokasi Kejadian Kecelakaan Di Kota Bengkulu. Jurnal Rekursif, 5(1), 55-66.

Sugiyono. (2014). Metode Penelitian Kuantitatif Kualitatif dan R\&D. Alfabeta.

Undang-Undang No.22 tahun 2009, Tentang Lalu Lintas dan Angkutan Jalan. (2009). 